Employment of Scientists in Government Services

Most of the March issue of State Service, the journal of the Institution of Professional Civil Servants, is occupied by the annual report of the Association; but the general secretary, Mr. Stanley R. Mayne, directs particular attention to the difficulty experienced by the Ministry of Aviation in filling posts at principal scientific officer-level as an example of the reluctance of scientists to enter the Scientific Civil Service. The press advertisements only produced five applications, and only one of these was judged worth interviewing, and he was not good enough to be selected. The Department had four other candidates, of whom three were selected and offered appointment but the only applicant from industry declined the offer. Three other scientists were afterwards interviewed and two were selected; one of these has already resigned. The annual report for 1960 , which records a membership of 53,923 , quoting the figures for recruitment of scientists from the recent report of the Civil Service Commission which are causing the Commissioners grave disquiet, is critical of the value of information collected by the Civil Service Pay Research Unit other than as a broad basis for discussion.

\section{Valuation and Rating of Scientific Institutions}

THE annual report for 1960 of the Parliamentary and Scientific Committee (Pp. 22. London : Parliamentary and Scientific Committee, 1961) contains a concise summary of the addresses and discussions during the year and of Dr. J. Killian's speech at the annual luncheon. It refers also to the European Parliamentary and Scientific Conference sponsored by the Committee, with the financial support of the Council of Europe, the Organization for European Economic Co-operation and the Foreign Office, in London, during March 21-23, 1961. The Rating Sub-Committee has again considered the position of scientific societies, and at a meeting on December 5 it was agreed to seek amendments to the Rating and Valuation Bill to secure that hereditaments given mandatory 50 per cent rating relief under clause 8 (1) include all hereditaments properly established for scientific purposes, and that the power given to rating authorities to reduce or remit the payment of rates chargeable in respect of such premises should be transferred to the Ministry of Housing and Local Government so that there should be central decision. It was also agreed to seek similar mandatory 50 per cent relief for all organizations qualifying for freedom from income tax under section 449 of the Income Tax Act, 1952 (relating to research associations).

\section{Smithsonian Institution}

THE annual report for 1960 of the United States National Museum is as usual a well-illustrated, bulky volume giving details of much curatorial work, an impressive account of research undertaken by, or in collaboration with, the staff, and a list of donors and their gifts covering nearly 2,500 accessions (Pp. vi +175 . Washington, D.C. : Government Printing Office, 1960). The modernization programme started about a decade ago continues in all departments, and the construction of the Museum of History and Technology is in progress and will be completed by March 1962. The building has been designed so that the collections will be shown under the best known modern con- ditions, and also maximum flexibility within the structure for future development has been a prime consideration. In geology events such as the devolopment of jaws and the transition of life from water to land have been demonstrated by diagrams and models. Among the unusual specimens displayed are a 14-ft. skeleton of the predatory Cretaceous fish Xiphactinus, and a slab from New Mexico showing the crowded bones of the amphibian Buettneria, entrapped in an evaporating Triessic swamp.

\section{The British Leather Manufacturers' Research Association}

THE ennual report for $1959-60$ of the British Leather Manufacturers' Research Association records a membership of some 75 per cent of the productive industry with a net increase in membership of 15 and a total income of $£ 70,134$, including a grant of $\mathfrak{f 2 1 , 9 0 0}$ from the Department of Scientific and Industrial Research (Pp. 70. Egham, Surrey : British Leather Manufacturers' Research Association, 1960). An effluent liaison officer and assistant analyst have been appointed to recommend and demonstrate modifications in leather-making processes designed to reduce effluent problems, and a new radioisotope research laboratory has been built, particularly for the study of chrome complexes in leather by radioisotope techniques. The report of the Director of Research refers to the maintenance of fundamental research on the constitution and properties of collagen and other constituents of hides and skins, the chemistry of vegetable tanners and the mechanical and elastic properties of collegen and leather fibres. In the enzyme unhairing of hides a bath-treatment at $80^{\circ} \mathrm{F}$. for three days ensured consistent removal of short hairs with tho long hairs, and small-scele trials indicate that no great difficulties should be experienced in vegetable tanning. An investigation of the factors in chrome-tanning processes which are important for satisfactory dyeing has commenced, and the leather properties which are required for good acceptance of pigment finish and good coversge are being investigated; investigations are being made on suede leather with the view of improving the colour fastness, particularly of black suede. Work on the edeptation of semi-chrome upper leather for moulded-sole footwear continued, but mechanical engineering work was discontinued and engineering work will be limited to chemical engineering topics, including effluent problems. Work on the deterioration of leather by heat, moisture and perspiration has lod to substantial advances in an understanding of the deterioration of leather by perspiration ; but in work on waterproofing of leather the study of laboratory testing methods now has priority, and an extensive testing programme in connexion with sheepskins and sheopskin leathers has been necessary. Besides outlining the programme of research, the report includes a list of publications during the year.

\section{The Cawthron Institute}

Tre annual report for 1959-60 of the Cawthron Institute, Nelson, New Zealand, records some changes in the scope of the Institute's research activities, and its facilitios for investigating the more fundamental aspects of plant nutrition have been extended by new equipment (Pp. 35. Nelson, N.Z. : Cawthron Institute). The Director's report reviews the progress 